\title{
Haemocytic neoplasia in Mediterranean mussels (Mytilus galloprovincialis) in the Slovene Adriatic Sea
}

\author{
Mitja Gombač ${ }^{a,{ }^{,},}$Rosvita Sitar ${ }^{b}$, Milan Pogačnik $^{a}$, Isabelle Arzul ${ }^{c}$ and Vlasta Jenčič ${ }^{d}$
}

\footnotetext{
a Veterinary Faculty of Ljubljana, Institute of Pathology, Forensic and Administrative Veterinary Medicine , Ljubljana , Slovenia

${ }^{\mathrm{b}}$ Veterinary Faculty of Ljubljana , National Veterinary Institute , Ljubljana , Sloveni

${ }^{c}$ Laboratory of Genetic and Pathology, Ifremer, La Tremblade, France

d Veterinary Faculty of Ljubljana, Institute for Breeding and Health Care of Game, Fishes and Bees, Ljubljana , Slovenia
}

*: Corresponding author : Mitja Gombač, email address : mitja.gombac@vf.uni-lj.si

\begin{abstract}
:
The health status of cultured and wild Mediterranean mussels in the Slovene Sea has so far been unexplored. Initially, 1280 adult Mediterranean mussels (Mytilus galloprovincialis), 960 from a shellfish farm and 320 from natural beds, were collected over a one-year period. Water temperature, oxygenation and salinity were measured at each sampling. Mussels were measured and weighted to calculate the condition index and microscopically examined for the presence of haemocytic neoplasia. Haemocytic neoplasia was detected in 14 mussels $(1.1 \%)$ with a higher prevalence in cultured mussels. Neoplastic cells singularly infiltrated the connective tissue, in small foci or diffusely. Necrosis and multifocal atrophy of digestive tubules were noticed in mussels with diffuse neoplasia, whereas severe haemocytic infiltration of connective tissue was seen in mussels with single neoplastic cells. Haemocytic neoplasia was more frequently observed in spring and autumn. The average condition index of mussels with haemocytic neoplasia was slightly higher than in healthy ones. This is the first report of haemocytic neoplasia in Mediterranean mussels in the Northern Adriatic Sea. The disease occurs only sporadically and to date no significant impact on the mussel population has been noted.
\end{abstract}

Keywords: haemocytic neoplasia ; Mediterranean mussels ; Mytilus galloprovincialis ; Slovene Sea 
39 A "probable neoplastic disease of the hematopoietic system" was first reported in oysters,

Crassostrea virginica and C. gigas, and in blue mussels (Mytilus edulis) from a population in Yaquina Bay, USA by Farley in 1969 . Later, morphologically similar alterations were diagnosed in many species of bivalves in various locations over the world (Barber, 2004) and were given different names, including disseminated neoplasia, leukaemia, haematopoietic or haemic or haemocytic neoplasia , leukocytic neoplasia, sarcomatous neoplasia or sarcoma . It is supposed that the disease is of haemocytic origin, albeit a progenitor cell type has never been firmly determined. Because of this, there is a possibility that more than one tissue may be of origin for this disorder (Barber, 2004).

So far, disseminated neoplasia has been diagnosed in 15 species of bivalves including oysters (Ostreidae), cockles (Cardiidae), clams (Tellinidae and Myidae ) and mussels (Mytilidae) . In mussels, it was named haemocytic neoplasia of mussels and has been diagnosed in blue (Mytilus edulis), Mediterranean (Mytilus galloprovincialis) and Pacific (Mytilus trossulus) mussels all over the world .

The disease is characterised by the proliferation of large, anaplastic, hypertrophied cells with large, hyperchromatic and often pleomorphic nuclei and high mitotic activity in the connective tissue, blood vessels and sinuses of the visceral mass, muscle and mantle tissue . In the early stages of the disease, only single abnormal cells or small foci of neoplastic cells are observed in the circulatory system . Later on, neoplastic cells progressively replace normal haemocytes . Subsequently the displacement, compression of gills, gonad and connective tissue and general degeneration and necrosis of tissues occur . The haemocytes lose their

60 defence capabilities and the capabilities of digestion, absorption and food transportation, which leads to starvation and death, but remission can also occur . 
In Mediterranean mussels only sporadic cases have been recorded to date .

The occurrence of haemocytic neoplasia in blue mussels (Mytilus edulis) is higher in late autumn and in winter, from October to March or from January to March . Older mussels are more frequently affected .

The aetiology of the disease is unknown. The transfer by inoculation of neoplastic cells and healthy haemocytes of diseased mussels to healthy mussels was successful . Some authors assume that the causative agent is a virus , but other possible factors are also marine pollution and biotoxins .

The Slovene Sea (Fig. 1) is part of the Gulf of Trieste, the northernmost end of The Adriatic Sea, where the Mediterranean pushes furthest into the European continent . The average depth of the sea is only about 17 metres and the deepest point is 37.25 metres deep . The seawater temperature varies considerably: during the summer the shallows can heat up to $30^{\circ} \mathrm{C}$ and the coastline can even freeze during very cold winters . The average temperature is $15.8^{\circ} \mathrm{C}$ and average salinity between 37 and 38\% . Many large and small rivers, groundwater and underwater springs have a strong effect on salinity, which fluctuates between $20 \%$ after abundant rainfall and 38\%o during late summer and winter . The oxygen concentration varies depending on the seawater temperature . The average oxygen concentration at the sea bottom is $6 \mathrm{mg} / \mathrm{l}$ in summer and $9 \mathrm{mg} / \mathrm{l}$ during winter .

The present study was performed to find out if the Mediterranean mussels from the northern Adriatic Sea are affected by haemocytic neoplasia and to determine its prevalence

\section{Materials and Methods}

\subsection{Mussel sampling}

Two sampling sites for collection of Mediterranean mussels (Mytilus galloprovincialis) were established in Slovene Sea: one in the Seča shellfish farm and one in natural shellfish beds 
near Piran (Fig. 1). Twelve samplings were performed in the shellfish farm (80 adult mussels were stripped directly from ropes at each sampling) and 11 (in December the collection of wild mussels was impossible due to the stormy sea) in natural beds (from 20 to 40 adult mussels were collected at each sampling), at a depth of approximately 3 meters, from November 2007 to October 2008. In total 1280 adult Mediterranean mussels comprising 960 from the shellfish farm and 320 from natural beds were collected throughout the year and included in our study.

Water temperature, oxygenation and salinity were measured at each sampling at the exact point where the mussels lived. Water temperature and oxygenation were measured using a thermometer "MultiLine P4 - Oxi 320 Set” with a dissolved oxygen probe (oxygen sensor) “CellOx 325” (WTW). Water salinity was measured using a hand-held refractometer "S/MillE. $S=0-100 \% "(A T A G O)$.

Live adult mussels were transported to the laboratory within one hour in a classic cooling bag. Sediment and fouling organisms attached to the shell were carefully removed. The mussel shells were then washed with fresh water.

\section{$2.2 \quad$ Measurements and condition index evaluation}

The length of the mussels was measured from the hinge to the longest part of the shell. The shell was opened and excess water was removed. The total weight of each mussel was measured and the flesh was afterwards carefully removed from the shell intact, drained on double absorbent paper and weighed. The total weight of the mussel and weight of the flesh were measured with an electronic balance PM 3000 (Metzler), accurate to 0.01g. The flesh condition index was calculated by means of the formula "condition index = fresh flesh weight x 100/total weight”. 
113 The shell and the flesh of mussels were macroscopically inspected for visible abnormalities

114 or lesions. A standard section through the visceral mass, including mantle, gill and gonads

115 was excised after weighing. Samples were immediately placed in $10 \%$ formalin solution for

116 not longer than 24 hours at room temperature and were routinely paraffin embedded. Four $\mu \mathrm{m}$

117 thick sections were stained with haematoxylin and eosin (HE) and one slide per mussel was

118 examined with a Diastar (Reichert-Jung) light microscope for the presence of neoplasias.

119 Morphometric analyses were performed on histological section photographs, using a DS-U2

120 (Nikon) digital camera and Microphot FXA (Nikon) microscope. Measurements of neoplastic

121 cells were performed using the computer programme NIS-Elements BR (Nikon) as follows:

122 the diameters of one hundred neoplastic cells and their nuclei were measured and the average

123 values of the measured parameters were calculated. Mitoses were counted in 10 high power

124 fields (HPFs) and the average value was calculated. Mitotic activity was scored as low ( $<5 / 10$

125 HPF), intermediate (5-10/10 HPF), or high (> 10/10 HPF).

126

127

\section{$128 \quad 3 \quad$ Results}

\subsection{Mussels and environmental data}

130 No mortality was detected in shellfish farms during the one year sampling period.

131 The average length of the cultured and wild mussels was 7.0 and $7.1 \mathrm{~cm}$, respectively. The

132 average total weight was $15 \mathrm{~g}$ for cultured and $17.4 \mathrm{~g}$ for wild mussels, the average weight of

133 the flesh was $4.15 \mathrm{~g}$ in cultured and $4.8 \mathrm{~g}$ in wild mussels. The average condition index was

13428.1 in cultured and 29.6 in wild mussels. 
135 The average seawater temperature varied from $9.1^{\circ} \mathrm{C}$ in winter to $24.1^{\circ} \mathrm{C}$ in summer, the

136 average seawater oxygenation from $11.6 \mathrm{mg} / \mathrm{l}$ in winter to $7.6 \mathrm{mg} / \mathrm{l}$ in summer and the average

137 salinity from $37.25 \%$ in winter to $38.1 \%$ in summer.

$138 \quad 3.2 \quad$ Macroscopic examination

139 Emaciation with a slight yellowish coloration of flesh, which was of jelly consistence, was

140 noticed in one mussel; in all the others there were no macroscopically visible changes. The

141 average condition index of all mussels with haemocytic neoplasia was higher than in healthy

142 ones (30.1 and 28.3, respectively) and was the highest in mussels with multifocal form

143 (33.05). The lowest condition index (12.5) was detected in a mussel with a diffuse form of the

144 disease.

145

$146 \quad 3.3 \quad$ Histopathological examination

147 Haemocytic neoplasia of mussels was diagnosed in 14 mussels, which represented a 1.1\%

148 prevalence. The affected mussels were without macroscopic abnormalities.

149 Twelve mussels (1.25\% prevalence) with haemocytic neoplasia were sampled in the shellfish

150 farm and two in natural beds (0.6\% prevalence). Two mussels from the shellfish farm were

151 affected with haemocytic neoplasia in March, three in May, two in June, one in July, one in

152 September, two in October and one in December. The two affected mussels from natural beds

153 were sampled in September.

154 Neoplastic cells were highly pleomorphic - spherical, oval, spindle and starry, and

155 anysocitotic ranging from $12.3 \mu \mathrm{m}$ to $30.1 \mu \mathrm{m}$ in diameter. They had large, hyperchromatic

156 and mainly rounded but often also pleomorphic nuclei from $4.3 \mu \mathrm{m}$ to $22.7 \mu \mathrm{m}$ in diameter

157 with finely dispersed or dense chromatin without nucleoli. Some bi- and tri-nucleated cells

158 were noticed. The nucleus to cytoplasm ratio was high. The number of mitoses was high -20

159 mitoses per 10 HPF were counted. In four mussels neoplastic cells diffusely infiltrated the 
160

connective tissue, blood vessels and sinuses of the visceral mass and gonads, in two mussels only small foci of neoplastic cells were noticed in the connective tissue of digestive gland tubules and gonads, whereas in eight mussels only single neoplastic cells were observed in the vessels and connective tissue of the digestive gland. A diffuse and multifocal form of the disease was observed only in cultured mussels, whereas single neoplastic cells were detected in six cultured and in two wild mussels (Figure 2).

Necrosis and multifocal atrophy of digestive tubules were observed in mussels with diffuse neoplasia, whereas severe haemocytic infiltration of connective tissue was observed in mussels with single neoplastic cells. No alteration was noticed in mussels with small foci of neoplastic cells. In two mussels with single neoplastic cells and in one mussel with foci of neoplastic cells, a mild infection with intracellular ciliates of mussels was observed.

\section{Discussion}

The prevalence of haemocytic neoplasia of mussels in the Slovene Sea was $1.1 \%$. Other authors also reported only sporadic cases of the disease in Mediterranean mussels and subsequently very low prevalences: $0.27 \%$ in Rias of Galicia in Spain , $0.45 \%$ in the Southern Mediterranean Sea in Italy , 0.5\% in the Black Sea in Romania and 3.4\% in Delta de l'Ebre in Spain . The prevalence of haemocytic neoplasia in cultured mussels was $1.25 \%$ and in wild mussels $0.6 \%$. Haemocytic neoplasia was more frequently observed in spring and in autumn and was less frequent in summer and winter. In January, February, April, August and November, no haemocytic neoplasia of mussels was detected. Elston observed haemocytic neoplasia in mussels in late autumn but also in winter, from October to March. Carrasco et al. found affected mussels in June and October, whereas Barber reported the major occurrence from January to March. Le Grand et al. also observed variations of disease intensity in 
cockles Cerastoderma edule throughout the year, which were not linked with seawater temperature.

Neoplastic cells were highly pleomorphic and anysocitotic, with large, hyperchromatic rounded or pleomorphic nuclei with finely dispersed or dense chromatin without nucleoli. Some bi- or even tri-nucleated cells were also observed. The nucleus to cytoplasm ratio was high and so was the number of mitoses. Many other authors also described haemocytic neoplasia of mussels as a proliferation of hypertrophied neoplastic cells with a large, hyperchromatic and often pleomorphic nucleus with finely dispersed chromatin , containing one or more prominent nucleoli or are without it . Ciocan and Sunila also noticed some binucleated cells. Several other authors observed that the nucleus to cytoplasm ratio and mitotic activity are high. Usheva and Frolova reported a high mitotic index from 0.9 to $1.9 \%$.

Barber reported that in the early stages of the disease, only single abnormal cells or small foci of neoplastic cells, morphologically resembling the haemocytes, are seen in the circulatory system. Later, neoplastic cells progressively replace normal haemocytes and are found throughout the various tissues . Diffuse infiltration of neoplastic cells was observed in four Slovene mussels, and small numbers of single neoplastic cells or small foci of cells were observed in vessels and connective tissue of digestive glands in 10 Slovene mussels. Zizzo et al. and Ciocan and Sunila found a diffuse distribution of neoplastic cells in the connective tissue of various organs and in blood vessels in all affected mussels. Villalba et al. observed a diffuse form of neoplasia in blood vessels and sinuses around the stomach.

Necrosis and multifocal atrophy of digestive tubules were observed in Slovene mussels with diffuse neoplasia whereas severe haemocytic infiltration of connective tissue was seen in mussels with single neoplastic cells. Fibrosis, displacement, compression of gills, gonad and connective tissue, atrophy of digestive diverticula and general degeneration and necrosis of 
tissues have been described in the diffuse form of haemocytic neoplasia . No tissue damage was observed in mussels with only single neoplastic cells .

The average condition index of Slovene mussel with haemocytic neoplasia was slightly higher

211 than that of healthy ones, albeit in some mussels with the diffuse form of the disease the

212 lowest condition index was detected. Barber reported that neoplastic haemocytes lose the

213 ability of digestion, absorption and food transportation, which leads to starvation of the

214 affected mussel. Leavitt et al. reported that the condition index of diseased clams was

215 significantly lower than that of healthy ones.

216 The potential etiological factors of haemocytic neoplasia of mussels are viruses (retrovirus),

217 environmental contamination, and bio-toxins . Hillman observed significantly higher

218 morbidity in mussels along both coasts of the United States in areas contaminated with

219 polycyclic aromatic hydrocarbons (PHA). In areas heavily polluted by pesticides, chromium,

220 mercury and cadmium, the morbidity in mussels was significantly lower compared to less

221 polluted areas. Usheva and Frolova found a connection between haemocytic neoplasia and

222 pollution also in Japan. Wolowicz et al. suspect that the cause of haemocytic neoplasia in

223 shellfish are heavily polluted sea sediments. Landsberg noticed that the occurrence of

224 haemocytic neoplasia coincided with outbreaks of several species of toxic dinoflagellates,

225 which may increase the susceptibility to neoplasia, particularly viral agents. No virus has been

226 isolated from the mussels affected with haemocytic neoplasia to date and affected Slovene

227 mussels were not checked for the presence of presumable viruses. Environmental

228 contamination and bio-toxins were also not evaluated in the Slovene Sea during our sampling,

229 but measurements of physical-chemical parameters, halogenated organic compounds and

230 metals in the Slovene Sea, cadmium and mercury content in sea sediments and mussel flesh

231 and the concentration of toxic phytoplankton, performed from 2003 to 2007 were under the

232 environmental quality standards. The analysed DNA damage, a consequence of mutagenic 
233 substances, was also under the level of normal damage caused by normal cellular mitoses in

2342001 in Slovene mussels. Other stressors may also have a negative impact on the host defence

235 mechanisms and also cause haemocytic neoplasia . In Slovene mussels, haemocytic neoplasia

236 occurred mostly in cultured mussels. This may also be a consequence of a stress caused by the

237 collection of seeds after their anchorage, their embedding in nylon socks and their removal,

238 cleaning and redistribution in bigger socks halfway through their cultivation.

239

240 The present investigation is the first study of haemocytic neoplasia in cultured and wild

241 Mediterranean mussels in the Northern Adriatic Sea. We can conclude that haemocytic

242 neoplasia of mussels occurs only sporadically in Slovene Mediterranean mussels. Only

243 diffuse form of the disease causes alterations in digestive tubules. It seems that haemocytic

244 neoplasia does affect the condition index of Slovene mussels, because the lowest condition

245 index was measured in some of the mussels with the diffuse form of the disease.

246 During our sampling and to date, no increased mortality or decline in shellfish growth and

247 overall production have been reported. We therefore believe that the prevalence of the disease

248 remains low and the impact on shellfish production negligible. However, if for any reason

249 (environmental contamination, bio-toxins, viruses, stress etc.) the prevalence of the disease

250 should increase, this might constitute a threat not only to shellfish production but also to wild

251 shellfish populations due to the negative impact of the disease on the bivalve reproductive

252 potential. We recommend regular biomonitoring of neoplasia in mussel populations from

253 Slovenian Sea to be carried out. Further research on the aetiology of the diseases is also

254 necessary.

255

256 Acknowledgements 
We are very grateful to the Fonda family, especially Dr. Irena Fonda, for their valuable help and the donation of cultured mussels. health, environment and food safety).

\section{References}

Ambrožič Š., J. Grbovič, et al., 2007, Enotna zbirka podatkov monitoringa kakovosti voda. Ljubljana: Slovenian Environmental Agency.

Barber B.J., 2004, Neoplastic diseases of commercially important marine bivalves. Aquat Living Resour 17(4), 449-466.

Bower S.M., 2006, Synopsis of infectious diseases and parasites of commercially exploited shellfish: haemocytic neoplasia of mussels.

Carrasco N., I. Arzul, et al., 2008, Delta de l'Ebre is a natural bay model for Marteilia spp. (Paramyxea) dynamics and life-cycle studies. Dis Aquat Organ 79(1), 65-73.

Carrasco N., I. Lopez-Flores, et al., 2007, Dynamics of the parasite Marteilia refringens (Paramyxea) in Mytilus galloprovincialis and zooplankton populations in Alfacs Bay (Catalonia, Spain). Parasitology 134, 1541-1550.

Ciocan C., I. Sunila, 2005, Disseminated neoplasia in blue mussels, Mytilus galloprovincialis, from the Black Sea, Romania. Mar Pollut Bull 50(11), 1335-1339.

Čermelj B., A. Malej, et al., 2003, Vzpostavitev Eurowaterneta za morje v Sloveniji: pilot study. National Institute of Biology, Marine Biological Station, 71pp.

Elston R.A., 1990, Other diseases, other molluscsMolluscs diseases. Seatle, University of Washington press, pp. 29-32.

Elston R.A., M.L. Kent, et al., 1988a, Progression, Lethality and Remission of Hemic Neoplasia in the Bay Mussel Mytilus edulis. Dis Aquat Organ 4(2), 135-142.

Elston R.A., M.L. Kent, et al., 1988b, Transmission of Hemic Neoplasia in the Bay Mussel, Mytilus edulis, Using Whole Cells and Cell Homogenate. Dev Comp Immunol 12(4), 719-727.

Elston R.A., J.D. Moore, et al., 1992, Disseminated Neoplasia of Bivalve Mollusks. Rev Aquat Sci 6(5-6), 405-466.

Farley C.A., 1969, Sarcomatoid proliferative disease in a wild population of blue mussels (Mytilus edulis). J Natl Cancer Inst 43(2), 509-516. 
Figueras A.J., C.F. Jardon, et al., 1991, Diseases and Parasites of Rafted Mussels (Mytilus galloprovincialis Lmk) - Preliminary-Results. Aquaculture 99(1-2), 17-33.

Hillman R.E., 1990, Incidence of neoplasia in west coast bivalves collected during phases 1, 2 and 3 of the Mussel Watch Program. Presented at the 1990 Mussel Watch Conference, Sequim, WA.

Hillman R.E., 1993, Relationship of environmental contaminants to occurrence of neoplasia in Mytilus edulis populations from east and west coast mussel-watch sites. J Shellfish Res 12, 109.

Kent M.L., M.T. Wilkinson, et al., 1991, Failure of Transmission of Hemic Neoplasia of Bay Mussels, Mytilus trossulus, to Other Bivalve Species. J Invertebr Pathol 57(3), 435436.

Landsberg J.H., 1996, Neoplasia and biotoxins in bivalves: Is there a connection? J Shellfish Res 15(2), 203-230.

Le Grand F., E. Kraffe, et al., 2010, Prevalence, intensity, and aneuploidy patterns of disseminated neoplasia in cockles (Cerastoderrna edule) from Arcachon Bay: Seasonal variation and position in sediment. J Invertebr Pathol 104(2), 110-118.

Leavitt D.F., J.M. Capuzzo, et al., 1990, Hematopoietic Neoplasia in Mya arenaria Prevalence and Indexes of Physiological Condition. Mar Biol 105(2), 313-321.

Lipej L., M. Orlando Bonaca, et al., 2004, Obravnavano območjeRaziskovanje biodiverzitete v slovenskem morju, Piran: Nacionalni inštitut za biologijo, Morska biološka postaja, pp. 11-24.

Mozetič P., L. Lipej, et al., 2008, Spremljanje ekološkega in kemijskega stanja morja in kakovosti vode za življenje morskih školjk in morskih polžev v letu 2007: letno poročilo 2008. . Piran: Nacionalni inštitut za biologijo, Morska biološka postaja.

NIB, 2002, Raziskave kakovosti morja: poročilo za 2001. Nacionalni inštitut za biologijo, Morska biološka postaja Piran.

Rejec Brancelj I., 2003, Morje. In: Uhan J., Bat M. (Eds.), Vodno bogastvo Slovenije. Ljubljana, Slovenian Environmental Agency, pp. 69-73.

Richter M., 2005, Naše morje: okolja in živi svet Tržaškega zaliva. Piran. pp 16-61, Sijart.

Tiscar P.G.-., N. Zizzo, et al., 1990, Dati preliminari sulla patologia infettiva ed infestiva dei molluschi eduli lamellibranchi allevati o raccolti sui litorali Pugliesi. Atti Soc Ital Sc Vet 44, 709-712.

Turk V., O. Bajt, et al., 2007, Kakovost morja in kontrola onesnaženja. Poročilo za leto 2006. Piran: Nacionalni inštitut za biologijo, Morska biološka postaja.

Turk V., O. Bajt, et al., 2005, Kakovost morja in kontrola onesnaženja. Poročilo za leto 2005. Piran: Nacionalni inštitut za biologijo, Morska biološka postaja.

Usheva L.N., L.T. Frolova, 2000, A connective tissue tumor in the mussel Mytilus trossulus from a polluted region of Nakhodka Bay, the Sea of Japan. Ontogenez 31(1), 63-70.

Villalba A., S.G. Mourelle, et al., 1997, Symbionts and diseases of farmed mussels Mytilus galloprovincialis throughout the culture process in the Rias of Galicia (NW Spain). Dis Aquat Organ 31(2), 127-139.

Wolowicz M., K. Smolarz, et al., 2006, Neoplasia in estuarine bivalves:effect of feeding behaviour and pollution in the gulf of Gdansk (Baltic sea, Polland). NATO Science Series IV: Earth and Environmental Series, 165-182.

Zizzo N., P.G. Tiscar, et al., 1991, Neoplasia in mitili (Mytilus galloprovincialis). Boll Soc Ital Patol Ittica 7, 19-21. 


\section{$349 \quad$ Figure captions}

350

351 Fig. 1 The Slovene Sea and sampling sites: Seča (black circle) and Piran (red circle)

352

353 Fig. 2 Haemocytic neoplasia of mussels (HE staining). A - single cells (arrows), B -

354 multifocal form, C - diffuse form, D - a neoplastic cell with a large, lobed, hyperchromatic 355 nucleus.

356 


\section{$358 \quad$ Figure 1}

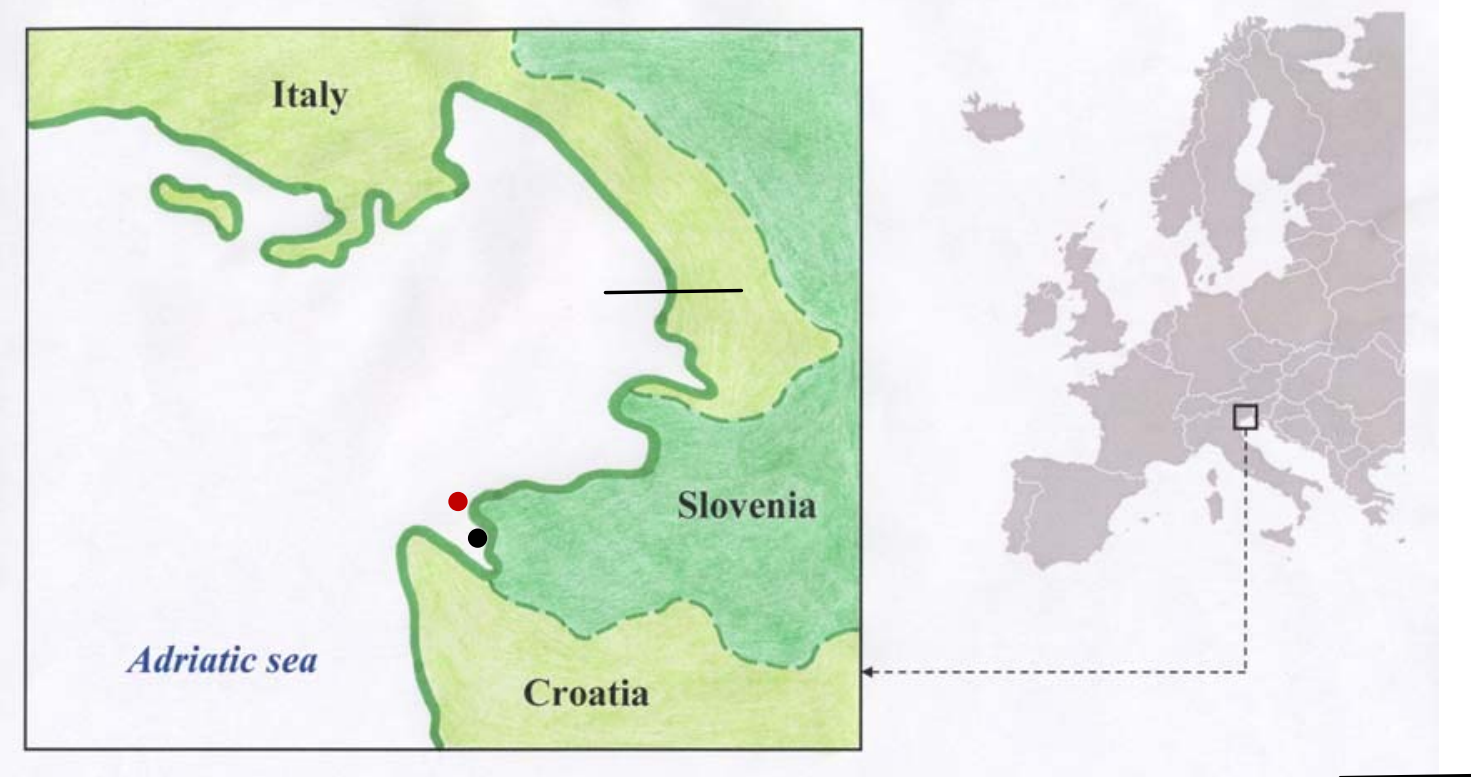

359

$360 \quad$ Figure 2

361

362

363

364

365

366

367

368

369

370
A.

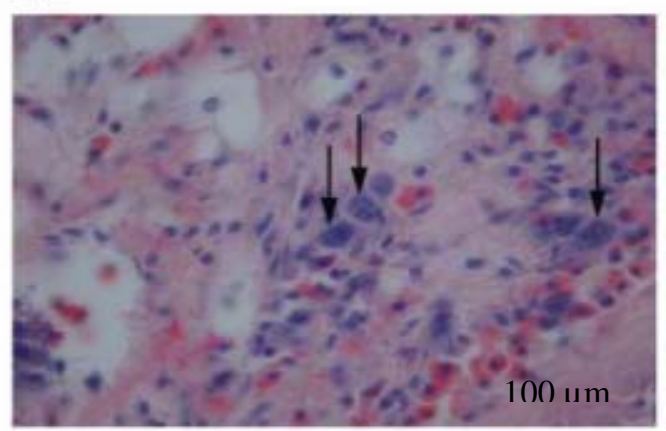

c.

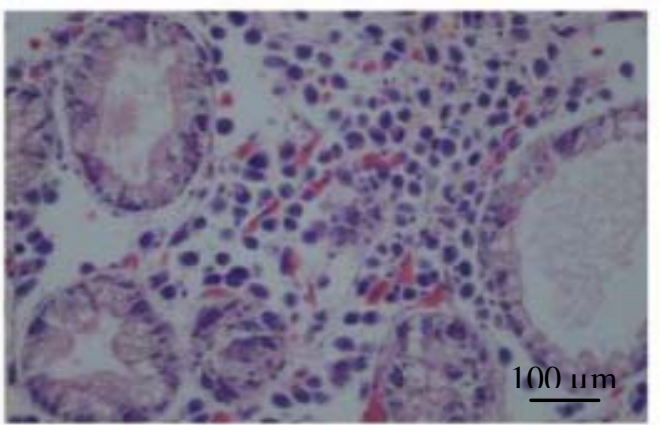

B.



D.

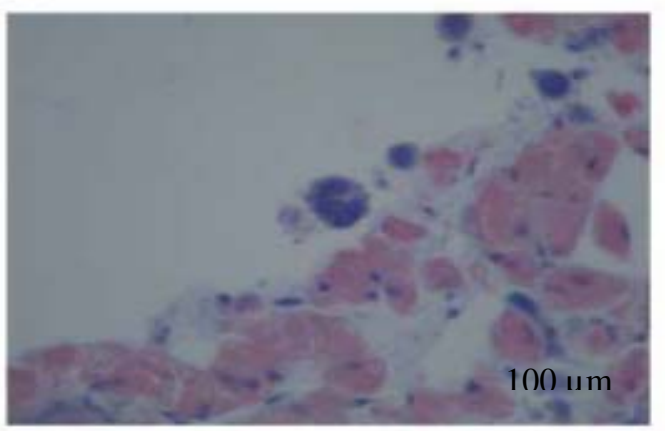

